\begin{tabular}{c}
\hline OKU Fen Bilimleri Enstitüsü Dergisi \\
Cilt 4, Sayi 2, 134-141, 2021
\end{tabular}

\title{
Yatırıma En Uygun Restoran Alanlarının CBS ile Belirlenmesi, Tunceli Örneği
}

\author{
Selim TAŞKAYA ${ }^{1 *}$, Neslişah ULUTAŞ ${ }^{2}$ \\ ${ }^{1}$ Artvin Çoruh Üniversitesi, Meslek Yüksekokulu, Mimarlık ve Şehir Planlama, 08100, Artvin, Türkiye. \\ ${ }^{2}$ Konya Teknik Üniversitesi, Mühendislik Fakültesi, Harita Mühendisliği Bölümü, Konya, Türkiye \\ ${ }^{1}$ https://orcid.org/0000-0002-4290-3684 \\ ${ }^{2}$ https://orcid.org/0000-0002-8941-3690 \\ *Sorumlu yazar: selim_taskaya@artvin.edu.tr
}

\begin{tabular}{|c|c|}
\hline Araştırma Makalesi & ÖZET \\
\hline $\begin{array}{l}\text { Makale Tarihçesi: } \\
\text { Geliş tarihi: } 16 \text { Aralık } 2020 \\
\text { Kabul tarihi:5 Nisan } 2021 \\
\text { Online Yayınlanma:1 Haziran } 2021\end{array}$ & $\begin{array}{l}\text { Coğrafi Bilgi Sistemleri, konuma bağlı öznitelik verilerini kullanarak grafik veya } \\
\text { grafik olmayan verileri toplayıp, farklı analiz yöntemleri ile işleyerek ilgiliye istediği } \\
\text { bilgiyi sunan bir bilgi sistemidir. Bu sistem nokta, çizgi ya da poligon tabanlı nesneler } \\
\text { oluşturularak yapılır. CBS 'nin, nokta, çizgi ya da poligon tabanlı nesnelerin analiz } \\
\text { edilmeleri AHP (Analitik Hiyerarşi Yöntemi), TOPSİS veya Proximity (Buffer) yani }\end{array}$ \\
\hline $\begin{array}{l}\text { Anahtar Kelimeler: } \\
\text { CBS } \\
\text { Analitik hiyerarşi yöntemi } \\
\text { Buffer analizi } \\
\text { Arcgis }\end{array}$ & $\begin{array}{l}\text { yakınlık uzaklık analizi vb. yöntemler doğrultusunda yapılmaktadır. Proximity } \\
\text { (Buffer) analizi, coğrafi detayların çevresinde belirli uzaklıklarda yeni alan detaylar } \\
\text { (tampon bölgeler) oluşturup söz konusu tamponlar içindeki detayları belirleme } \\
\text { işlemidir. Tamponlar içinde kalan coğrafi detaylar üzerinde istenilen sorgulamalar } \\
\text { yapılabilir. Yakınlık analizi, özellikle konuma dayalı uygulamalarda, etkileşim alanı } \\
\text { belirleme gibi uygulamalarda sıklıkla kullanılmaktadır. Çalışma alanı, Tunceli ili bazlı } \\
\text { merkez toplam } 8 \text { mahallede gerçekleşmiştir. İl merkezi toplam } 8 \text { mahalleden } \\
\text { oluştuğundan tamamı çalışma içerisine alınmıştır. Hedef, coğrafi bilgi sistemlerinden } \\
\text { yararlanarak yatırıma en uygun restoran kurulabilecek en uygun noktaların tespit } \\
\text { edilmesidir. Bu bağlamda Tunceli il verileri imar sınırları içerisinde yola cephesi olan } \\
\text { parseller seçilip, imar adası } 3000 \text { ile } 15000 \mathrm{~m}^{2} \text { olacak adalarda çalışma yapılmıştır. } \\
\text { Eğitim kurumlarına } 150 \text { m, sağlık kurumlarına en çok } 400 \text { m, mevcut restoranlara en az } \\
150 \text { m etkisinde uzakta olacak şekilde tüm katmanlar belirlenmiştir. Buffer analizi ile } \\
\text { yakınlı uzaklık parametreleri doğrultusunda işletmecilerin iş yapabilecek, müşterilerin } \\
\text { ihtiyaçlarına cevap verebilecek yerleri tespit edilmeye çalışıldı. Bu tip restoran, iş } \\
\text { merkezi alışveriş merkezi, ticari, konut ticari uygun alanların belirlenmesinde kolaylik } \\
\text { sağlayacaktır. Buna göre ArcMap yardımıla katmanlar oluşturulmuş, bunun } \\
\text { sonucunda restoran kurulabilecek en uygun noktalar daireler şeklinde tampon bölgeler } \\
\text { oluşturularak kartografik harita üretilmiştir. }\end{array}$ \\
\hline
\end{tabular}

\section{Determining the Most Suitable Restaurant Areas for Investment by GIS, The case of Tunceli}

\section{Research Article}

Article History:

Received: 16 December 2020

Accepted: 5 April 2021

Published online: 1 June 2021

\begin{abstract}
Geographic Information Systems is an information system that collects graphical or nongraphical data using location-dependent attribute data, processes them with different analysis methods and provides the information they want. This system is made by creating point, line or polygon based objects. GIS's point, line or
\end{abstract}




\section{Keywords:}

CBS

Analytical hierarchy method Buffer analysis

Arcgis polygon analysis of based objects AHP (Analytical Hierarchy Method), TOPSIS or Proximity (Buffer) ie proximity distance analysis and so on. It is done according to methods Proximity (Buffer) analysis creates new field details (buffer zones) at certain distances around the geographical details andIt is the process of determining the details inside. Geographical details inside the buffers. Requests can be made on it. Proximity analysis, especially location based applications, in applications such as determining interaction area is used. Study area, Tunceli-based center in total 8 neighborhoodsh as been realized. Since the city center consists of 8 neighborhoods, all of them were included in the study. The target is the most suitable investment by using geographic information systems. It is the determination of the most suitable places to establish a restaurant. In this context, Tunceli provincial data parcels within the zoning boundaries was selected and work was carried out on islands with development island between 3000 and $15000 \mathrm{~m}^{2}$. Education institutions $150 \mathrm{~m}$, health institutions at most $400 \mathrm{~m}$, existing restaurants at least. All layers were determined at a distance of $150 \mathrm{~m}$ from the effect. With the buffer analysis, in line with the proximity and distance parameters, the locations of the operators that can work and meet the needs of their customers were tried to be determined. This type of restaurant, business center, shopping center, commercial, residential commercial areas will make it easier to determine suitable areas. According to this layers are created with the help of ArcMap, resulting in the most suitable cartographic map by creating buffer zones in the form of dots circles produced.

To Cite: Taşkaya S., Ulutaş N. Yatırıma En Uygun Restoran Alanlarının CBS ile Belirlenmesi, Tunceli Örneği. Osmaniye Korkut Ata Üniversitesi Fen Bilimleri Enstitüsü Dergisi 2021; 4(2): 134-141.

\section{Giriş}

Coğrafi Bilgi Sistemleri (CBS), coğrafya ve topoğrafyaya altlık olarak oluşturulan verilerin depolanıp saklanması için bir araya getirilen verilerin analizi ve işlenmesine olanak sağlayan bilgi sistemidir [1]. CBS, coğrafi temelli mekânsal verileri yöneten, modelleyen, veri tabanları sistem yönetimi (VTSY) ile sorgulayan sistemlerin tamamıdır [7, 16]. $\mathrm{Bu}$ işlemler ArcMap, OpenGL, vb. uygun paket yazilımlar aracılığ 1 ile yapılabilmektedir [3]. Bu sayede meydana gelen veri ve yöntemler bütünü coğrafi referanslı herhangi bir unsuru sayisal ortama aktarma imkânı sunar. Aynı zamanda UTM ya da TM projeksiyonlarla bu verilerin gerekli kartoğrafik haritalara dönüştürülmesine olanak sağlar [4]. Programlama dili oluşturulan CAD paket yazılımları ile yeni yönetim veri sistemleri haritaya dönüştürülmüş olur [3]. CBS, harita çizimi ile tematik haritaların üretilmesine meydan veren her türlü coğrafik unsurların semboller yardımıyla görsel olarak sunma olanağı sunar [2].
Çalışmada restoran kurulabilecek en uygun alanlar tampon yöntemi ile belli mesafe parametreleri doğrultusunda oluşturulup haritalanması sağlandı.

$\mathrm{Bu}$ uygulamanın amacı coğrafi bilgi sistemlerinden yararlanarak yatırıma en uygun restoran alanının bulunmasıdır. $\mathrm{Bu}$ amaç doğrultusunda, kentte yol orta eksenlerini gösteren yol katmanı, yapılaşma şartlarını gösteren imar katmanı, mahalle sinırlarını gösteren mahalle katmanı, diğer restoranların konumlarını gösteren restoran katmanı ve bunların yanı sıra eğitim kurumlarını gösteren eğitim katmanı ile sağlık kurumlarını gösteren sağlık katmanları topolojileri kuruldu. Bu bilgiler 1şı̆̆ında sekiz mahalleyi kapsayan bir il bölge uygulama alanı olarak alındı. Şu parametrelere bakılarak işlem uygulandı. Yola cephesi olmalı, imar adas1 3000-15000 $\mathrm{m}^{2}$ büyüklüğünde ve yap1 nizamı en az 4 kat olmalıdır. Eğitim kurumlarına en çok $150 \mathrm{~m}$. uzaklıkta, sağlık kurumlarına en çok $400 \mathrm{~m}$. mesafede, mevcut restoranların etki alanından en az $150 \mathrm{~m}$. uzakta olmalıdır. 


\section{Yakınlık (Proximity) Analizi}

Tampon analizi (buffer analysis) olarak da adlandırılan yakınlık analizi, coğrafi detayların çevresinde belirli uzaklıklarda yeni alan detaylar (tampon bölgeler) oluşturup, söz konusu tamponlar içindeki detayları belirleme işlemidir. Tamponlar içinde kalan coğrafi detaylar üzerinde istenilen sorgulamalar yapılabilir. Yakınlık analizi, özellikle konuma dayalı uygulamalarda, etkileşim alanı belirleme gibi uygulamalarda sıklıkla kullanılmaktadır[6]. Coğrafi nesneler için aşağıda belirtilen 3 tip yakınlı analizinden bahsedilebilir.

\subsection{Nokta tabanll yakınlık analizi}

Nokta tipindeki herhangi bir coğrafi detay merkez kabul edilmek üzere belirlenen yarıçapta bir daire oluşturulur. Oluşturulan bu daire, yeni alan detay yani tampon bölgedir ve bu bölgenin içinde kalan coğrafi detaylar tespit edilir. Örneğin, bir GSM verici istasyonu $10 \mathrm{~km}$ yarıçapında bir alanı etkiliyorsa, söz konusu istasyonun etki alanına giren ulaşım ağları ve yerleşim merkezleri nokta tabanlı yakınlık analizi ile tespit edilir (Şekil 1). Ayrıca oluşturulan tampon bölgenin dış sınırıyla yeni bir tampon bölge daha üretilebilmektedir [4].

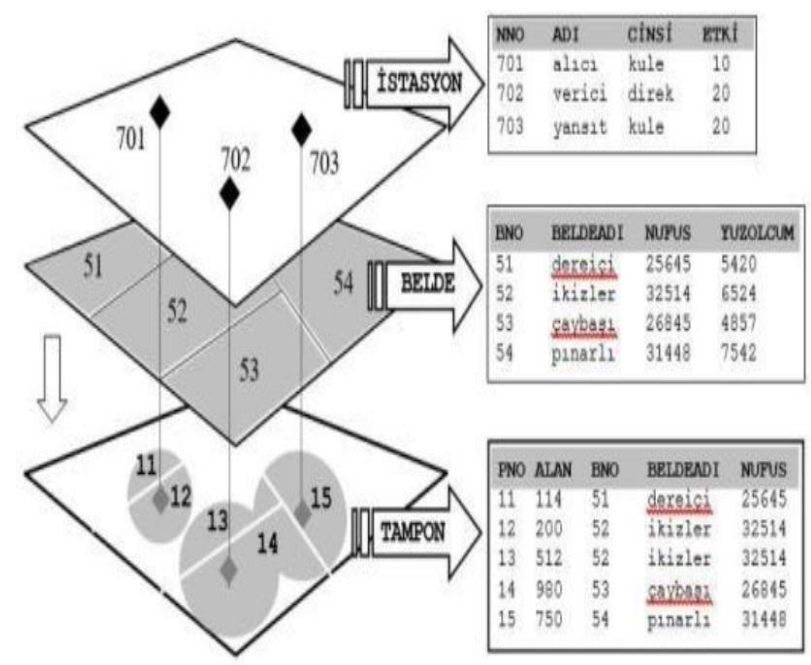

Şekil 1. Nokta tabanlı yakınlık analizi [4].

\section{2. Çizgi tabanlı yakınlık analizi}

Çizgi tipindeki herhangi bir coğrafi detayın istenilen uzaklıkta çevrelenerek yeni bir tampon bölge oluşturulması ve bu bölge içindeki detayların tespit edilmesi işlemidir. Örneğin;
Bir yol genişletme çalışmasında, mevcuttaki yol güzergâhı yol ekseni boyunca $40 \mathrm{~m}$ genişletilmek istenirse, söz konusu genişletme ile kamulaştırma yapilacak olan araziler ve bu arazilerin mal sahipleri kolaylıkla tespit edilir [4].

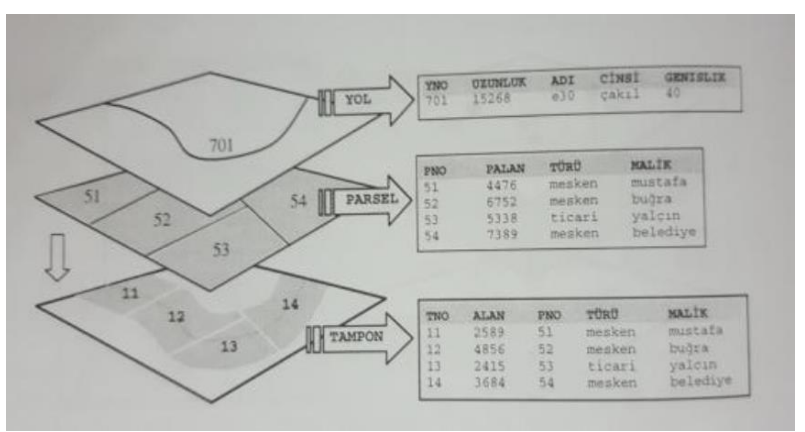

Şekil 2. Çizgi tabanlı yakınlık analizi [4].

\subsection{Poligon tabanl yakınlı analizi}

Poligon tipindeki herhangi bir detayın istenilen uzaklıkta çevrelenerek yeni tampon bölgelerin oluşturulması ve bu bölgelerin içinde kalan detayların tespit edilmesi işlemidir. Örneğin, bir gölü çevreleyen kıyı kullanım alanı tespit edilebilir. Gölü çevreleyen 200 m'lik mesafede yapılaşma yasağı bulunan bir kuşak oluşturulabilir ve gölün dış sınırı $200 \mathrm{~m}$ daha genişmiş gibi yeni bir sınır elde edilir (Şekil 3). Bu sayede yeni oluşturulan tampon bölgede yapılaşma kontrol edilmiş olur. Ayrıca, söz konusu bölge sınırları içinde kalan kaçak binaları tespit etmek de kolaylaşmış olur. $\mathrm{Bu}$ analiz türünde de, nokta ve çizgi tabanlı yakınlık analiz türlerindeki gibi mevcuttaki poligon yapısı istenildiği kadar genişletilebilir ve yine yeni bir tampon bölge oluşturulabilir.

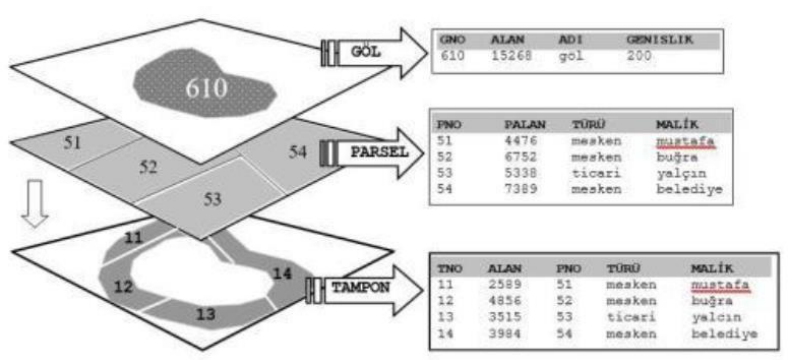

Şekil 3. Poligon tabanlı yakınlık analizi [4]. 


\section{Uygulama Alanı}

Tunceli ili, Kuzey Doğu Anadolu bölgesinde yer almaktadır. İl 38 derece 19 dakika ve 40 derece 26 dakika Doğu boylamı; 39 derece 36 dakika ve 38 derece 46 dakika Kuzey enlemleri arasında konumlanmaktadır. Şehir dağlık bir topoğrafyaya sahip olmakla birlikte ilin güneyinde Elazığ, doğusunda Bingöl, batısında Sivas illeri bulunmaktadır [8].

Tablo 1. Tunceli İli Bilgileri [10]

\begin{tabular}{|c|c|c|c|c|c|c|}
\hline & & & & \\
\hline
\end{tabular}

Tablo 2. Tunceli İl Mahalle Verileri [10]

Tablo 1' e baktığımızda, Tunceli şehir nüfusu 100,677 'dir. Nüfusun $\% 66,85$ 'i şehirlerde ikamet etmektedir. İlin topoğrafik yüzölçümü 7,583 $\mathrm{km}^{2}$ dir. Şehirde $\mathrm{km}^{2}$ başına 11 kişi düşmekte iken bu değer merkez ilçesinde 34 olarak değişmektedir. TÜİK'in 2019 yılı verilerine bakıldı̆̆ zaman şehirde 8 İlçe, 9 belediye ve bu belediyelerde 43 mahalle ve 364 köy mevcuttur [9].

Tablo 2' de, ilin 8 tane mahallesine ve nüfus bilgilerine yer verilmiştir. $\mathrm{Bu}$ bilgiler doğrultusunda ArcMap de mevcut tabaka verileri oluşturulmuştur.

\begin{tabular}{|c|c|}
\hline Mahalle Adı & Mahalle Nüfusu \\
\hline Atatürk & 19,447 \\
\hline Moğultay & 2,882 \\
\hline Cumhuriyet & 5,124 \\
\hline Alibaba & 2,249 \\
\hline Aktuluk & 1,116 \\
\hline İsmat İnönü & 1,042 \\
\hline Esentepe & 1,012 \\
\hline Yeni & 901 \\
\hline
\end{tabular}


Tablo 3. Mahalle Katman Bilgileri.

\begin{tabular}{|c|c|c|c|}
\hline MAHALLE ADI & BINA & BAĞIMSIZ BÖLÜM & MÜLK HAK \\
\hline SAYISI & 39 & 944 & 567 \\
\hline Moğultay & 58 & 592 & 199 \\
\hline Atatürk & 33 & 645 & 1778 \\
\hline Aktuluk & 78 & 1249 & 1580 \\
\hline Yeni & 29 & 883 & 795 \\
\hline Esentepe & 10 & 1029 & 55 \\
\hline İsmet İnönü & 45 & 392 & 159 \\
\hline Cumhuriyet & 19 & 576 & 385 \\
\hline Alibaba & 24 & 1657 & 449 \\
\hline Alibaba & 15 & 850 & 382 \\
\hline Esentepe & 36 & 2845 & 580 \\
\hline İsmet İnönü & 75 & 1535 & 602 \\
\hline Cumhuriyet & 44 & 1787 & 891 \\
\hline Aktuluk & 55 & 4200 & 475 \\
\hline Atatürk & 55 & 1617 & 39 \\
\hline Moğultay & 90 & 641 & \\
\hline Yeni & & & \\
\hline
\end{tabular}

Tablo 3 de ArcMap'de mahalle katmanını oluştururken öznitelik verilerinin bulunduğu kısmın geri plandaki datalarıdır. $\mathrm{Bu}$ şartları sağlayan birden çok imar adası olması durumunda bir mühendis gözüyle hangi adanın daha uygun olduğuna bakıld1. Şekil, alan, anayollara cephe durumu, yollar üzerindeki bina sayıları gibi kriterler dikkate alındı.
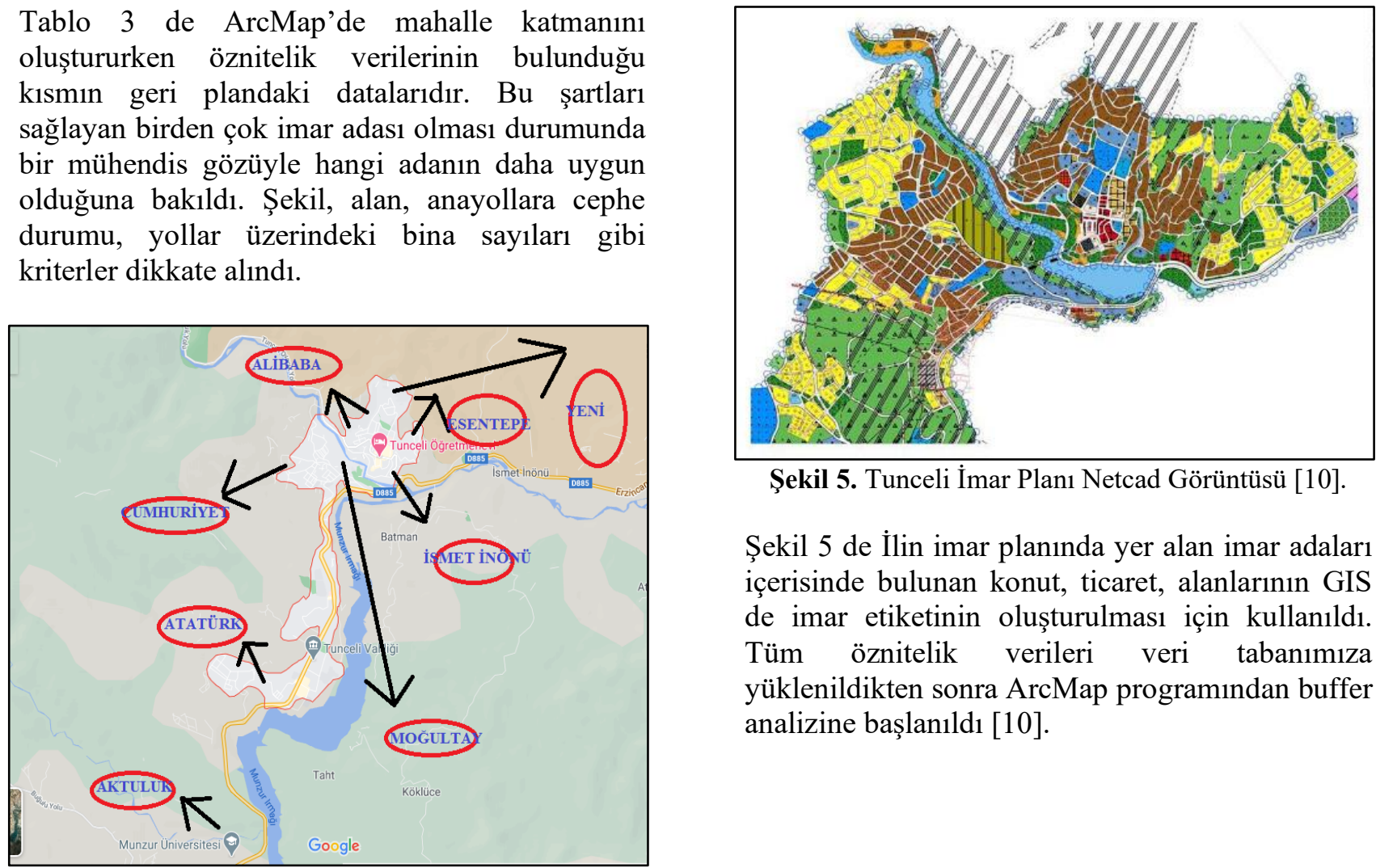

Şekil 5. Tunceli İmar Planı Netcad Görüntüsü [10].

Şekil 5 de İlin imar planında yer alan imar adaları içerisinde bulunan konut, ticaret, alanlarının GIS de imar etiketinin oluşturulması için kullanıldı. Tüm öznitelik verileri veri tabanımıza yüklenildikten sonra ArcMap programından buffer analizine başlanıldı [10]. 


\section{4. İşlem Adımları}

Tablo 4. ArcMap de tüm işlemlerin yapılma siralamasi.

\begin{tabular}{|l|}
\hline ArcMap programının açılması ve projeye başlangıç \\
\hline Veritabanı oluşturma \\
\hline Verilerin veri tabanına aktarılması \\
\hline Katmanlar için "Label” (etiket) oluşturma \\
\hline Çalışma bölgesinin belirlenmesi \\
\hline Seçilen Mahallelerin Katman Haline Getirilmesi \\
\hline Clipping Aracının Kullanımı İle Katmanların \\
Bölgelendirilmesi \\
\hline $\begin{array}{l}\text { Tabakaların Yeni "Data Frame” İçerisinde } \\
\text { Düzenlenmesi }\end{array}$ \\
\hline Tabaka Adlarının Düzeltilmesi \\
\hline Mevcut Öznitelik Tablolarına Veri Ekleme \\
\hline Tablo Oluşturma Ve Birleştirme Eksik Yolların \\
Tamamlanması \\
\hline Buffer Analizleri Ve Uygun Ticaret Alanının Tespiti \\
\hline Layout hazırlanması \\
\hline Çıktı sayfasının farklı bir formata dönüştürülmesi \\
Export Map"
\end{tabular}

Tablo 4'de, ArcMap programında yol, imar, cephe, mahalle, eğitim, sağlık, restoran bilgilerin maksimum ve minumum uzaklık yakınlık kriterleri girildikten sonra veri tabanına, bu işlem basamağı takip edilir ve istenilen kartografik yaklaşık harita elde edilmektedir.

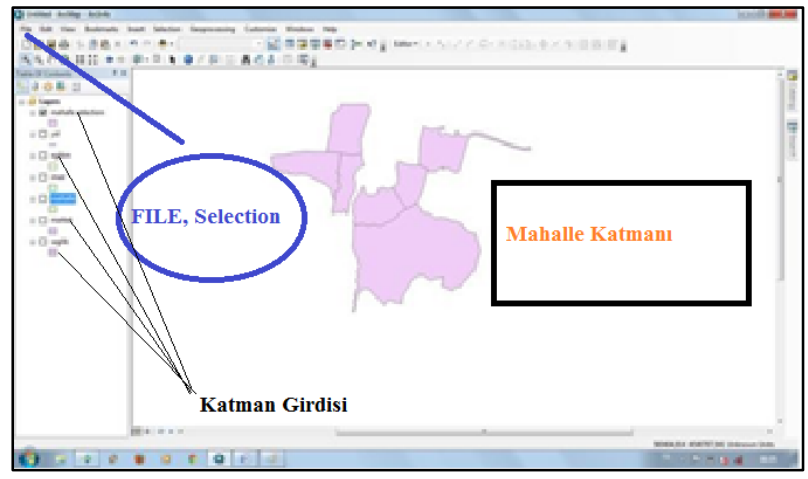

Şekil 6. ArcMap Mahalle Sınır Görüntüsü

Şekil 6'da, ArcMap10.0 açılarak add data'dan eğitim, imar, mahalle, restoran, sağlık ve yol bilgileri tabakalar şeklinde açılır. Selection modülündeki select by attiributes'ten istenilen 8 mahalle seçilir. Mahalle üzerinde sağa tıklanarak selection'dan Create Layer From Selected Features seçilerek istenilen mahallelerin bulunduğu yeni bir katman oluşturulur.

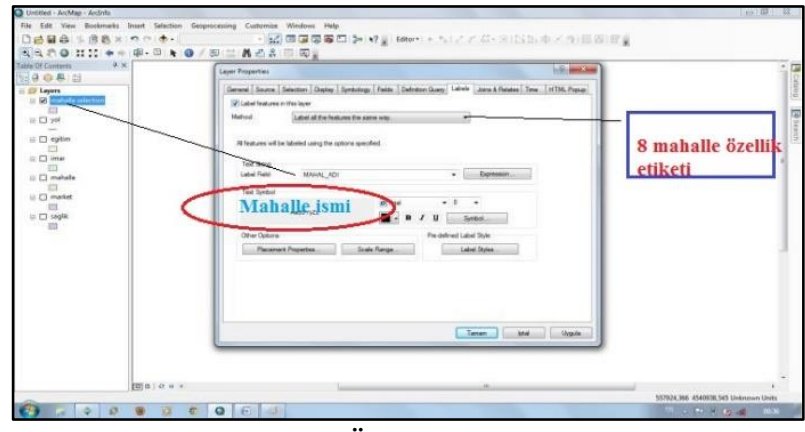

Şekil 7. Mahalle Öznitelik Veri Görüntüsü

Şekil 7'de, mahalle selection katmanında sağa t1klanarak properties'teki labels seçilerek label features in this layer işaretlenip mahalle isimlerinin gözükmesi sağlanır.

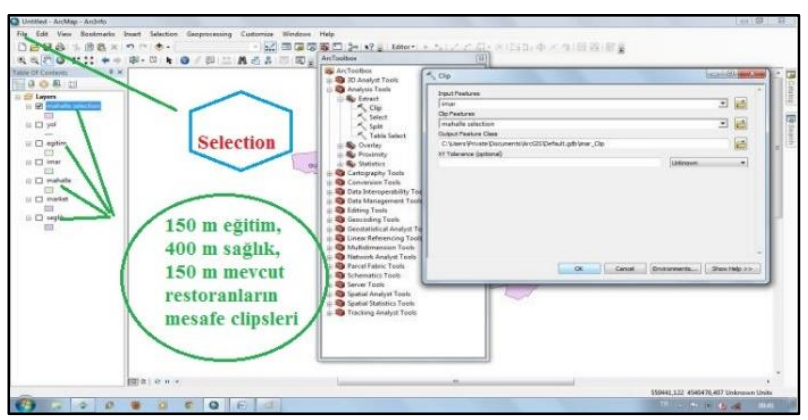

Şekil 8. Clips Görüntüsü

Şekil 8'de, ArcToolbox $>$ Extract $>$ Clip seçilerek mahalle selection'a gore yeniden eğitim imar yol sağlık restoran clipleri oluşturulur. Bu işleme bir anlamda silme diyebiliriz, sadece çalışma bölgesine ait veriler söz konusu olur.

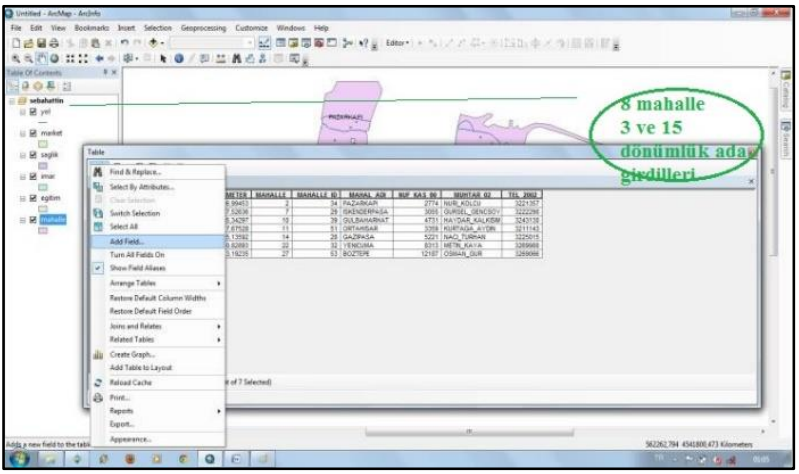

Şekil 9. Öznitelik Veri Görüntüsü

Şekil 9'da, Insert>Data Frame seçilerek yeni bir yer açılır buraya bölgemize ait clip'ler atılarak çalışma sahası oluşturulur. Üzerine çift tıklanarak adı ve Map ve Dispay değerleri değiştirilir. Clip olarak oluşturulan katmanlar yeni yere kopyalanır. 
Katmanların üzerinde sağ tıklanılarak properties $>$ General seçilerek bütün isimler düzeltilir. Katmanlar üzerinde sağ tıklanarak öznitelik bilgilerine eklemeler yapılır. Ör: mahalle için yapılacak olursa Table $>$ Table options $>$ Add Field eklemeler yapılarak öznitelik bilgileri çoğaltılır. Girilecek sayının büyüklügüne göre text double vb. seçilir.

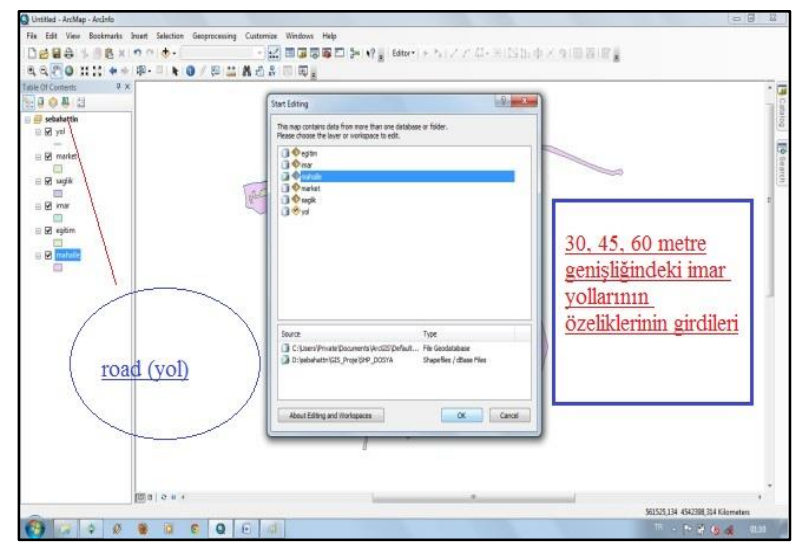

Şekil 10. Yol Güzergah Görüntüsü

Şekil 10 ve 11' de, bu işlemler diğer tabakalar içinde aynı yollarla yapılır. Anket veriler katmanı da oluşturulur. Bozuk olan ve birleşmeyen yerleri bulunan yol güzergâhı editör yardımıyla birleştirilmesi gerçekleştirilir.

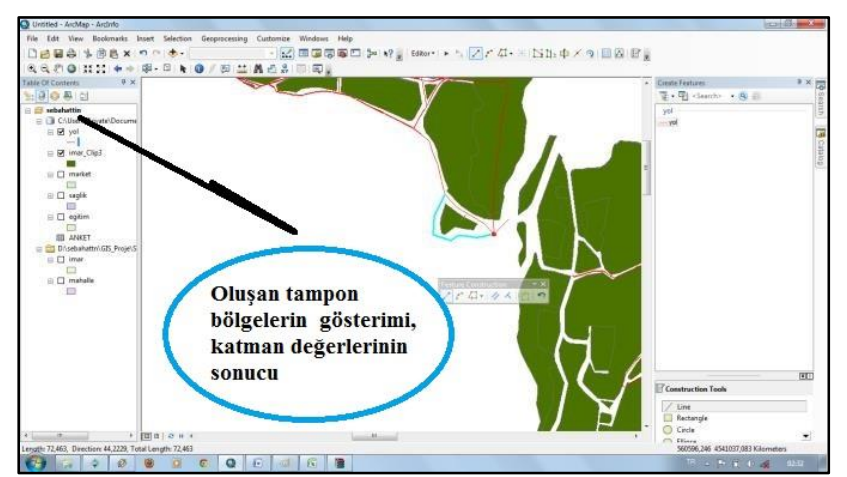

Şekil 11. Poligon Buffer Analizi Görüntüsü

Şekil 12'de yakınlık (Buffer) analizleri yapılarak uygun yerler belirlenir. Polygon şeklinde oluşturulan tampon yerlere uzaklığ 1 en uygun yeri restoran olarak seçmemiz gerekir.

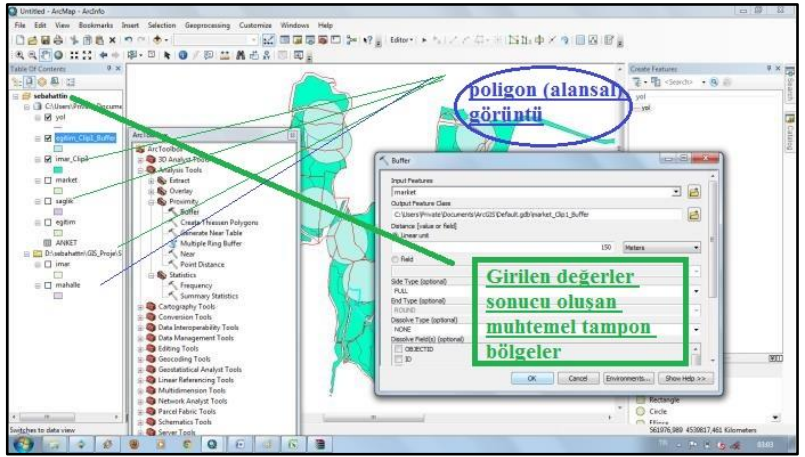

Şekil 12. Analiz Kriter Girdi Görüntüsü

Şekil 13'de, sağlık=400 m, eğitim=150 $\mathrm{m}$, restoran $=150 \mathrm{~m}$ çaplı buffer analizleri yapılır [5].

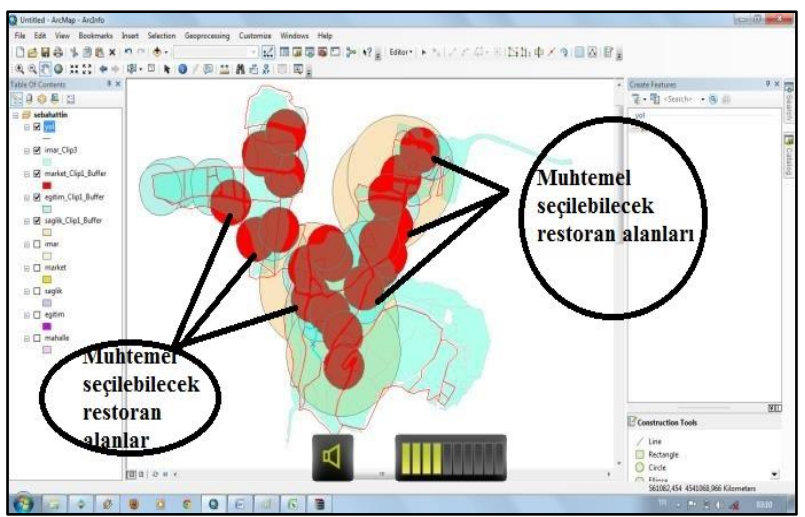

Şekil 13. Oluşan Tampon Bölge Görüntüsü

Şekil 13'de, restoran yerini göstermek için yeni bir katman açılır ve bu katmanla restoran alanı olabilecek yerler imar adasinda ve yola cephesi olacak şekilde çizilir. Herhangi bir öznitelik bilgisinden koordinat bilgileri alınır. Restoran yerini seçerken dikkat ettiğimiz, buffer analiziyle seçilmiş olan kriterlere uygun uzaklıkta olmalıdır. Buffer uygunluğu sağlandıktan sonra seçilecek yerin hem imarl hem de yola cephesi olmas1 gerekmektedir [5]. $\mathrm{Bu}$ kriterleri sağlayan yerlerden istenilen yer restoran yerimiz olabilir. 


\section{Sonuç ve Öneriler}

Öznitelik verilerinin olduğu her durumda, akarsu, havza, baraj, katı atık depoları, yol güzergâhı vb. vektörel verinin oluşturulmasında çeşitli analiz yöntemleri mevcuttur. AHP, TOPSIS ya da Buffer yani uzaklık- yakınlık analizi bu çalışmalarda kullanılan standart yöntemlerdendir. Genelde en s1k tercih edilen yöntem ise Buffer analiz yöntemi olmaktadır [7]. Bu çalışma kapsamında da Buffer analizi yöntemi tercih edilmiştir. İmar planları üzerinde, eğitim kurumu olan parsellere $150 \mathrm{~m}$, sağlık alanı parsellerine $400 \mathrm{~m}$, yola cephesi olan parseller katman olarak girildi. İmar adalar1 yüzölçüm değerleri $3000 \mathrm{~m}^{2}$ ve $15000 \mathrm{~m}^{2}$ olarak katmanlara girildi. Tüm bu katmanlar işığında yakınlık uzaklık analizi yapılarak çapsal daireler olacak şekilde muhtemel alanlar imar planına GIS ortamından altlık olarak işılendi. Bu şekilde GIS' ten katman değerler girilerek hedeflenen amaca yönelik imar işlemlerinde, altlık haritalama çalışmaları yapılması mümkün olacaktır. Sayısal işletmen planlar1, yol güzergâhları tespiti, atık ve içme suyu hatları, AFAD acil toplanma alanlarının bu yöntemle planlanması mümkün olacaktır.

\section{Çıkar Çatışması Beyanı}

Makale yazarları aralarında herhangi bir çıkar çatışması olmadığını beyan ederler.

\section{Araștırmacıların Katkı Oranı Beyan Özeti}

Yazarlar makaleye eşit oranda katkı sağlamış olduklarını beyan ederler.

\section{Kaynakça}

[1] Huisman O., de By RA. Principles of geographic information systems, An Introductory Textbook (4th Edition), 2009; ITC, Enschede, The Netherlands.

[2] Değerliyurt M., Çabuk SN. Defining the geography by geographical information systems, January, 2015.

[3] Fazal S. GIS Basics, New Age International (P) Ltd., Publishers, New Delhi, 2008.

[4] Yomralığlu T. Coğrafi Bilgi Sistemleri Temel Kavramlar ve Uygulamalar (3. Bask1), 2005; Akademi Kitabevi, Trabzon

[5] Gül S., Taşkaya S. ARCGIS yazılımı ile kıyı bilgi sistemi sayısallaştırma uygulaması, Gökova Örneği, Uluslararası Doğu Anadolu Fen Mühendislik ve Tasarım Dergisi 2009; 1(1). 29-48.
[6] Erdoğan BB. Coğrafi bilgi sistemleri ile katı atık düzenli depolama tesisi yer seçimi, Ondokuz Mayıs Üniversitesi Fen Bilimleri Enstitüsü Yüksek lisans Tezi, s:85, 2019.

[7] Ulutaş N., Tanrıverdi A. MapInfo yazılımı ile tematik haritaların üretilmesi Konya ili örneği. Uluslararası Doğu Anadolu Fen Mühendislik ve Tasarım Dergisi 2019; 1(1): 49-65.

[8]Url-1:http://www.esri.com/what-isgis/overview\#overview_panel (Erişim:15.09.2014)

[9] Url-2:https://tr.wikipedia.org/wiki/Tunceli_(il)

[10]Url-3:https://www.nufusu.com/merkeztunceli-mahalleleri-nufusu, 2019.

[11]Url4: https://www.google.com.tr/maps/search/tunceli+m ahalleleri/@39.09954,39.5280043,14z_Türkiye İstatistik Kurumu, 2019. 